\title{
Direct foamed and nano-catalyst impregnated solid-oxide fuel cell (SOFC) cathodes
}

\author{
Sodith R. Gandavarapu ${ }^{\mathrm{a}, \mathrm{b}}$, Katarzyna Sabolsky ${ }^{\mathrm{b}}$, Kirk Gerdes ${ }^{\mathrm{a}}$, Edward M. Sabolsky ${ }^{\mathrm{a}, \mathrm{b}, *}$ \\ a US DOE-National Energy Technology Laboratory, 3610 Collins Ferry Road, P.O. Box 880, Morgantown, WV 26507, USA \\ ${ }^{\mathrm{b}}$ Department of Mechanical and Aerospace Engineering, West Virginia University, PO Box 6106,Morgantown, WV 26506, USA
}

\section{A R T I C L E I N F O}

Article history:

Received 15 November 2012

Accepted 26 December 2012

Available online 3 January 2013

\section{Keywords:}

SOFC

Cathode

Direct foam

Impregnation

Nanomaterial

\begin{abstract}
A B S T R A C T
A binder system containing polyurethane precursors was used to in situ foam (direct foam) a $\left(\mathrm{La}_{0.6} \mathrm{Sr}_{0.4}\right)_{0.98}\left(\mathrm{Co}_{0.2} \mathrm{Fe}_{0.8}\right) \mathrm{O}_{3-\delta}$ (LSCF) cathode composition upon a yttrium-stabilized zirconia (YSZ) electrolyte coated with a porous $\sim 10 \mu \mathrm{m}$ thick cathode active layer. The YSZ electrolyte was $\sim 110 \mu \mathrm{m}$ in thickness, and a full cell was created by application of a $\mathrm{Ni} /\left(\mathrm{Ce}_{0.9} \mathrm{Gd}_{0.1}\right) \mathrm{O}_{2}$ cermetas the baseline anode. Cells possessing the foamed LSCF cathode were compared to cells constructed via standard methods in terms of resultant microstructure, electrochemical performance, and introceptive character. The foamed cathode tended to possess a high level of tortuous porosity which was ellipsoidal and interconnected in character. Both the standard and foamed cathode structures were subjected to an infiltration process, and the resultant microstructure was examined. The impregnation efficiency of the foamed cathode was at least $\sim 10 \%$ greater per deposition than that of an unfoamed porous LSCF cathode. The SOFC with the Pt nano-catalyst impregnated foamed cathode demonstrated a maximum power density of $593 \mathrm{~mW} / \mathrm{cm}^{2}$ utilizing wet $\mathrm{H}_{2}$ fuel, which is $52 \%$ higher than a SOFC with the baseline Pt-impregnated LSCF cathode $\left(\sim 390 \mathrm{~mW} / \mathrm{cm}^{2}\right)$ at $800{ }^{\circ} \mathrm{C}$. The cathode compositional and microstructural alterations obtainable by foaming led to the elevated power performance, which was shown to be quite high relative to standard SOFCs with a thick YSZ electrolyte.
\end{abstract}

C 2013 Published by Elsevier B.V.

\section{Introduction}

Solid oxide fuel cells (SOFCs) are attractive systems for the efficient electrochemical conversion to electricity of the chemical energy stored in gas and liquid fuels such as hydrogen, carbon monoxide, methane, coal syngas, and liquid hydrocarbon fuels. One issue that limits the commercialization of SOFC systems is related to the long-term degradation of the fuel cells, which can be correlated to the high operation temperature. In order to lower the operation temperature, and potentially increase cell life, the oxygen reduction reaction (ORR) at the SOFC cathodes must be improved. A recent strategy used to enhance oxygen reduction kinetics of traditional ( $\mathrm{La}, \mathrm{Sr}) \mathrm{MnO}_{3}$ (LSM) and LSCF cathodes is through the liquid impregnation of a nano-catalyst within the final sintered cathode microstructure [1]. The inclusion of the nano-catalyst extends the overall triple-phase boundary (TPB) area and alters the oxygen reduction mechanism by providing

\footnotetext{
* Corresponding author at: Department of Mechanical and Aerospace Engineering, West Virginia University, PO Box 6106, Morgantown, WV 26506, United States.

E-mail addresses: Sgandava@mix.wvu.edu (S.R. Gandavarapu), Kathy.Sabolsky@mail.wvu.edu (K. Sabolsky), Kirk.Gerdes@netl.doe.gov (K. Gerdes), Ed.Sabolsky@mail.wvu.edu (E.M. Sabolsky).
}

alternative adsorption and ion/electron spillover sites. A few reports indicated up to a two times improvement in fuel cell performance for $\mathrm{Cu}$ and $\mathrm{Ce}$ oxide nano-catalyst within the cathode microstructure [2-5]. The nano-catalyst is typically added by dropping or dipcoating a liquid based solution or dispersion of the nano-catalyst, which leaves a dispersion of the particle distributed over the presintered cathode microstructure. A low temperature-firing step is usually required to bond the nano-catalyst to the pre-sintered cathode backbone microstructure.

Previous literature demonstrates the effectiveness of the nanocatalyst impregnation in SOFC cathodes for improving oxygen reduction reaction [1,5-11]; unfortunately, the impregnation process may be time and labor intensive to incorporate the required nano-catalyst content within the open porosity. A well connected deposition of nano-catalyst into an electrode is typically only achieved by repetitive impregnation steps, which leads to more costly processing [11]. In addition, as the open cathode porosity is filled with the precipitated salts, the ability to infiltrate the porous structure to the active cathode (near the electrolyte interface) becomes more of an issue [12]. In this work, a novel in situ direct foaming process was utilized to form open and interconnected porosity throughout the cathode current collector. This porosity provided a microstructure to retain high intrinsic cathode performance, while at the same time, providing an open 
porous network to permit the efficient deposition of nanocatalyst to the active cathode area.

\section{Experimental}

The electrolyte-support membranes were fabricated from $8 \mathrm{~mol} \%$ YSZ powder (Daiichi Kigenso Kagaku Kogoyo Co., LTD, Japan) by a tape-casting, lamination process, and sintering ( $\sim 110 \mu \mathrm{m}$ final thickness). $\mathrm{A} \sim 3 \mu \mathrm{m}$ thick $\mathrm{Ce}_{0.9} \mathrm{Gd}_{0.1} \mathrm{O}_{2}$ (GDC) buffer layer was incorporated between the electrolyte and both electrodes by screen-printing and firing onto the electrolyte at $1350{ }^{\circ} \mathrm{C}$ for $1 \mathrm{~h}$. The GDC used in this study was synthesized using a conventional co-precipitation method [12]. A 50 vol\% NiO (HPGNO, Novamet, Wyckcoff, NJ)-50 vol\% GDC composite was mixed with an ink vehicle (J2M, 63/2, Johnson Matthey, UK). The ink was screen-printed and sintered at $1350{ }^{\circ} \mathrm{C}$ for $2 \mathrm{~h}$ to a thickness of $\sim 50 \mu \mathrm{m}$. The LSCF powder was synthesized by a solid-state process and attrition-milled to an average surface area of $5 \mathrm{~m}^{2} / \mathrm{g}$. A $50 \mathrm{vol} \%$ LSCF- $50 \mathrm{vol} \%$ GDC composite was formed as an active cathode composition and was printed on the cathode side of the cell ( $\sim 10 \mu \mathrm{m}$ thickness). For the baseline samples, a pure LSCF ink was printed over the active area and sintered to $1150{ }^{\circ} \mathrm{C}$ for $1 \mathrm{~h}$. The alternative cathode architecture was fabricated by printing a LSCF ink containing polyurethane precursors, which were similar to precursors previous demonstrated for direct foaming filled polyurethanes $[13,14]$. The ink was composed of LSCF powder and 8:4:1 polymer precursor composition (isoscyanate:polyol:surfactant). The precursor materials used in this work were polymethylene isocyanate (Volanate M220, Dow Chemicals), polyethylene glycol (PEG200, Aldrich) and polyoxyethylene sorbitan monooleate (Tween 80 Fluka). These polymer components were added to the J2M ink vehicle and printed over the active layer within an argon filled glove box. On exposure to ambient atmosphere (relative humidity $45-55 \%$ ), the polymerization reaction was initiated, and the $\mathrm{CO}_{2}$-blowing reaction resulted in the foaming of the printed LSCF structure. The LSCF/polymer thin film gel was then fired in a similar manner as the baseline (unfoamed) cathode microstructure $\left(1150{ }^{\circ} \mathrm{C}\right.$ for $1 \mathrm{~h}$ ).

An aqueous platinum precursor $\left(\mathrm{H}_{2} \mathrm{Pt} \cdot \mathrm{Cl}_{6} \cdot 6 \mathrm{H}_{2} \mathrm{O}\right.$, Alfa AesarPremion) solution was prepared at a $0.1 \mathrm{M}$ concentration, and this solution was used for the impregnation process. This solution was impregnated into the cathode with micro-pipette $(10-100 \mu \mathrm{L}$, Eppendorf International). The calcination of the impregnated cathode was performed at $850^{\circ} \mathrm{C}$ for $1 \mathrm{~h}$. The weight change of the impregnated structure was monitored until the catalyst level reached $5 \mathrm{wt} \%$ of cathode initial weight. The scanning electron microscope (SEM) imaging and energy-dispersive spectroscopy
(EDS) analysis of the half-cells with the above-mentioned compositions were performed using a JEOL 7600 SEM microscope.

The SOFCs were mounted on an alumina tube fixture with a pair of $9 \times 9 \mathrm{~mm}$ platinum mesh and wire as the current collectors for both electrodes. Six light dots of LSCF and Ni metal inks were used to secure the interconnect leads on the cathode and anode, respectively. The cell was then heated to $800{ }^{\circ} \mathrm{C}$ at $1-$ $2{ }^{\circ} \mathrm{C} / \mathrm{min}$. under $60 \mathrm{sccm}$ of argon gas within the anode chamber and ambient air within the cathode chamber. After the cell reached $800{ }^{\circ} \mathrm{C}$, the anode atmosphere was slowly transitioned to $100 \mathrm{sccm}$ of moist $\mathrm{H}_{2}\left(3 \% \mathrm{H}_{2} \mathrm{O}\right)$. Cell power curves $(V-I-P$ curves) data was collected using Solatron SI-1287 interface and an SI-1252 frequency response analyzer for the electrochemical impedance spectroscopy (EIS).

\section{Results and discussion}

Initial direct foaming experiments were completed with a low LSCF solids loading within the organic carrier. Fig. 1a displays the SEM micrograph of a cathode generated from a 20 vol\% LSCF loading in the ceramic-polymer precursor suspension. The average density for this sample measured by image analysis of SEM micrographs (using National Institute of Health (NIH) ImageJ) was $\sim 14 \%$ theoretical density ( $86 \%$ porosity) with $>20 \mu \mathrm{m}$ pore size. In a subsequent specimen, the LSCF solids loading was increased to $70 \mathrm{vol} \%$, while still maintaining the same precursor composition stated above. Fig. 1b shows a different resultant microstructure with an array of elongated or interconnected porous channels and a mixture of fine porosity between the LSCF particles. A polished cross-section of the foamed LSCF cathode on the substrate was analyzed using Image J with a subprogram developed by Impoco et al. [15]. The average porosity level was found to be $46.5 \%$ calculated from nine images at various magnifications (500-2000 $\times$ ) across the film thickness. The calculated two-dimensional mean pore perimeter length was $17.7 \pm 7.54 \mu \mathrm{m}$, with an average two-dimensional pore area of $\sim 15.9 \mu \mathrm{m}^{2}$ and a circularity factor of 6.9 . The circularity factor was calculated by dividing the pore perimeter value by the Ferret's diameter, with a circularity factor farther from $\pi$ (3.14) indicating a departure from an isotropic pore shape towards an interconnected and elongated channel shape. For comparison, an unfoamed LSCF cathode fired at $1150{ }^{\circ} \mathrm{C}$ onto the YSZ electrolyte (using no polyurethane precursor mixture) displayed an average porosity level of $43.1 \%$ with a two-dimensional pore area of $7.9 \mu \mathrm{m}^{2}$ and a circularity factor of 3.1. Interestingly, the average pore size for both samples was $\sim 4 \mu \mathrm{m}$.

The microstructures of the in situ foamed and baseline cathodes were then impregnated with nano-catalyst. The nano-Pt composition was chosen for its high stability and low reactivity
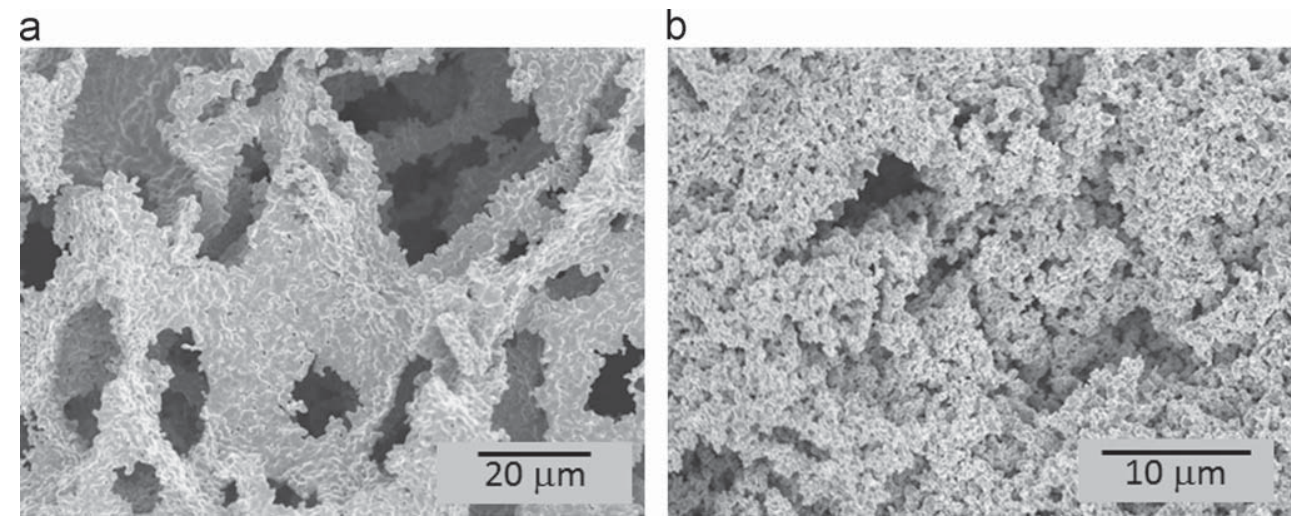

Fig. 1. Back-scattered SEM micrographs of the direct foamed LSCF cathodes with (a) $20 \%$ and (b) $70 \%$ solids loading and sintered at $1150{ }^{\circ} \mathrm{C}$. 
with the LSCF composition; therefore, the processing benefits can be directly evaluated without misinterpretation due to potential chemical interaction or surface modification of the LSCF cathode backbone (as is the case for nano-Ag or - $\mathrm{Cu}$ oxide incorporation) [16-18]. The amount of catalyst per infiltration step was monitored. The primary calcinations were performed after the $1 \mathrm{st}$ and 2nd infiltration steps at $450{ }^{\circ} \mathrm{C}$ for $1 \mathrm{~h}$, which resulted in the production of $\mathrm{Pt} / \mathrm{PtO}_{x}$ and some carbonaceous content. Final calcination was completed after further infiltration cycles (at $850{ }^{\circ} \mathrm{C}$ for $1 \mathrm{~h}$ ). Fig. 2 displays the accumulative normalize weight after each impregnation/calcination step. The catalyst weight was normalized as weight per volume to account for slight differences in thickness between the foamed and baseline cathodes. The sudden decrease in weight after the 3rd step reflects the removal of the carbonaceous content from all steps to that point. The foamed cathode showed the ability to accept a higher catalyst solution volume (and thus, higher solid nano-catalyst amount) after every step with similar porosity level ( $\sim 40-45 \%$ theoretical). The average amount of the precursor solution added per impregnation step was $2.45 \pm 0.25 \mathrm{~g} / \mathrm{cm}^{3}$ over 5 impregnation steps, whereas for the baseline was $0.845 \pm 0.12 \mathrm{~g} / \mathrm{cm}^{3}$. The results are well correlated with the above-discussed microstructural characteristics, where the interconnected and high porosity of foamed cathode assisted in providing open channels for efficient impregnation.

The cross-sectional SEM images of the impregnated samples were taken on a fractured surface of a nano-catalyst (5 wt\%) impregnated LSCF cathode foamed over a YSZ electrolyte. Fig. 3 displays the micrographs of the area $\sim 2-5 \mu \mathrm{m}$ above the beginning of the cathode active layer, which is important since the

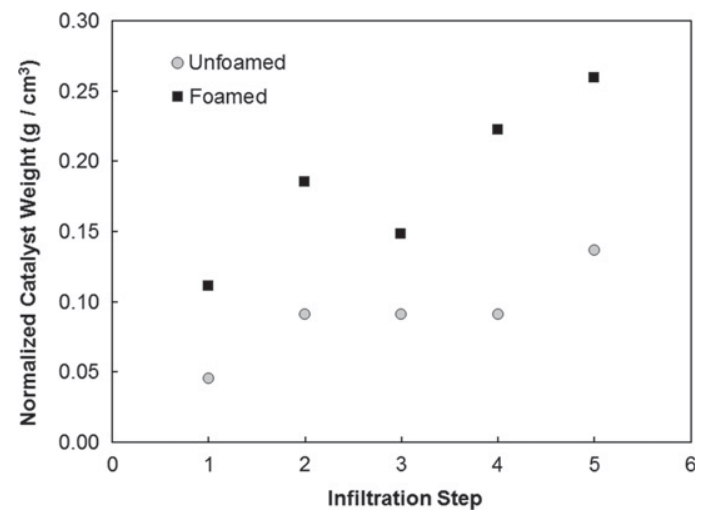

Fig. 2. Normalized weight of nano-Pt catalyst incorporated into the microstructure of the baseline and foamed cathode after each impregnation step. enhancement for the oxygen reduction reaction (ORR) would be expressed by infiltrating this active area. Fig. 3a shows the absence of any significant Pt nano-particles within this area near the electrolyte surface. The SEM micrograph in Fig. 3b shows a strong presence of the Pt throughout the thickness of the foamed sample, especially in the area near the active cathode interface. Also, it was observed that agglomerations of the Pt formed in the baseline, while a fine dispersion of nano-particles were seen in the foamed sample (compare Fig. 3a and b). This agglomeration in the baseline sample may be related to the pooling of the solution in various areas, since penetration through the porosity was limited.

The voltage-current-power $(V-I-P)$ performance data for the button cell SOFCs were tested with foamed and unfoamed LSCF cathodes using moist $\mathrm{H}_{2}$ fuel at $800{ }^{\circ} \mathrm{C}$. The SOFCs were mounted on an alumina tube and interconnected with Pt leads. The area specific resistance (ASR) values were calculated from the slope of the linear portion for the voltage-current density data. The performance of the SOFC with in situ foamed cathode showed a significant improvement over the baseline (unfoamed) cell. The cell with the foamed cathode displayed an average maximum power density of $514 \mathrm{~mW} / \mathrm{cm}^{2}$ (ASR $\approx 0.52 \Omega \mathrm{cm}^{2}$ ), which is $43 \%$ higher than the cells with the baseline cathode $\left(360 \mathrm{~mW} / \mathrm{cm}^{2}\right.$, ASR $\approx 0.73 \Omega \mathrm{cm}^{2}$ ), as shown in Fig. 4. For reference, the cell's electrolyte should contribute $\sim 0.30 \Omega \mathrm{cm}^{2}$ to the total ASR for the stated thickness at $800{ }^{\circ} \mathrm{C}$. The same cathode microstructures were impregnated with the $\mathrm{Pt}$ precursor using the five-step

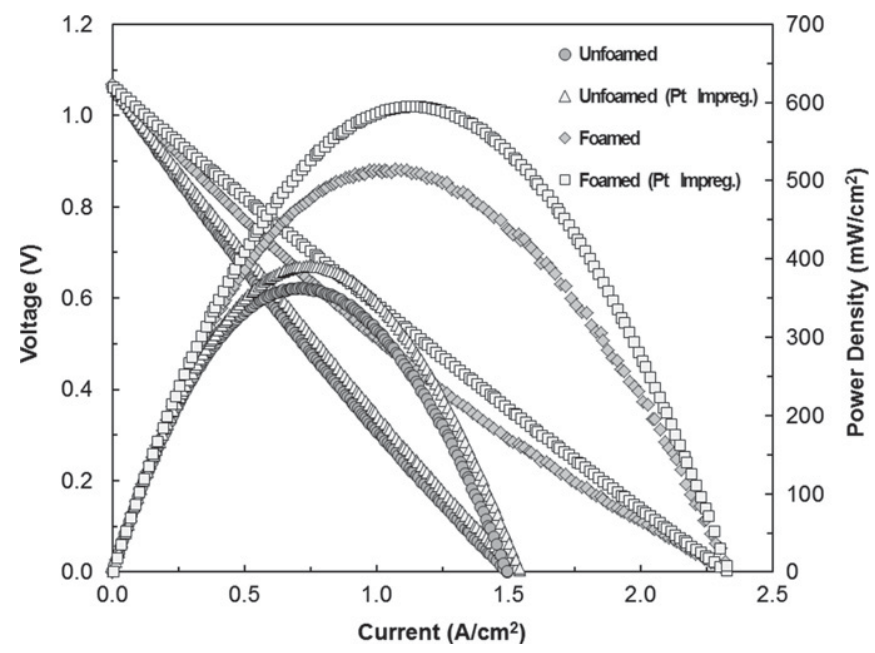

Fig. 4. $V-I-P$ performance curves of SOFC button cells that possessed a LSCF cathode that was unfoamed, foamed, unfoamed/Pt-impregnated, and foamed/Ptimpregnated. The SOFCs were measured at $800{ }^{\circ} \mathrm{C}$ with wet- $\mathrm{H}_{2}$ fuel. a

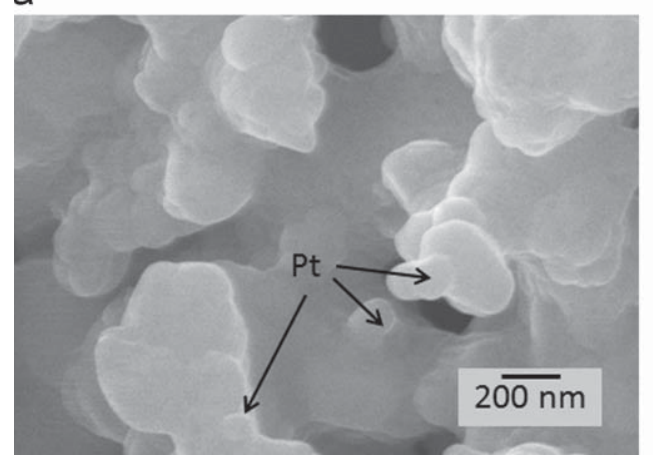

b

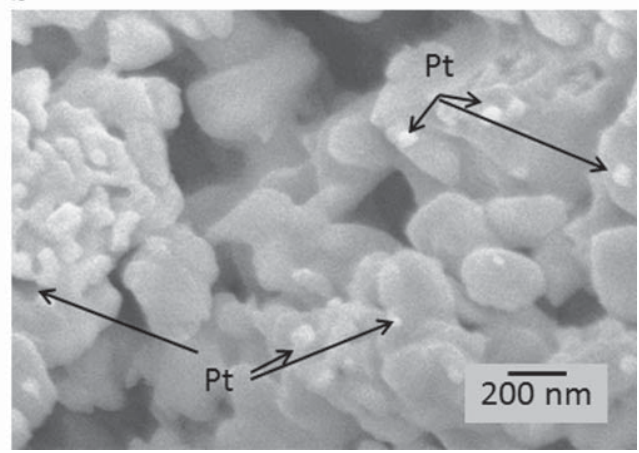

Fig. 3. SEM micrograph of the impregnated (a) baseline (unfoamed) and (b) foamed LSCF cathode at a distance of $\sim 2-5 \mu \mathrm{m}$ from the active cathode layer. 
impregnation and thermal processing method. It must be restated that the foamed sample at this point contained nearly twice the loading of the baseline sample due to the restricted ability of this structure to accept the catalyst impregnation solution (Fig. 3). The cell with the impregnated foamed cathode displayed a maximum power density of $593 \mathrm{~mW} / \mathrm{cm}^{2}$ (ASR $\approx$ $0.46 \Omega \mathrm{cm}^{2}$ ), which is $14 \%$ higher in power than the unimpregnated foamed cathode $\left(514 \mathrm{~mW} / \mathrm{cm}^{2}\right)$. This performance increase is twice that demonstrated recently by other researchers for Pt-enhancement of LSCF and LSM cathodes ( 7-8\%) at $800{ }^{\circ} \mathrm{C}$ $[8,18,19]$. The SOFC baseline cell with a Pt-impregnated LSCF cathode displayed a maximum power density of $\sim 390 \mathrm{~mW} / \mathrm{cm}^{2}$ (ASR $\approx 0.71 \Omega \mathrm{cm}^{2}$ ) at $800{ }^{\circ} \mathrm{C}$. This accounts for $\sim 7.7 \%$ higher power performance value over that of an un-impregnated baseline cell $\left(\sim 360 \mathrm{~mW} / \mathrm{cm}^{2}\right)$, as shown in Fig. 4. This improved performance can be attributed to the higher content of the Pt loading within the electrode and the homogeneous dispersion of fine catalyst particles deep within the cathode microstructure. Again, it must be stated that the loading was achieved with a higher degree of processing efficiency, leading potentially to a lower number of impregnation steps in the future to achieve a desired loading level.

\section{Conclusion}

The use of an in situ foaming process was used for the first time to fabricate porous LSCF cathode architectures with a mixed pore size range and a tortuous porous microstructure. The average pore area and circularity factors were twice as high as that demonstrated for an unfoamed LSCF cathode. The microstructure formed by this foaming process resulted in an electrode with a much lower cathodic polarization and an increase in maximum power performance by $\sim 43 \%$. The open and interconnected cathode pore structure also provided a higher level of efficiency in the impregnation of the cathode, which resulted in increased oxygen reduction kinetics. Future optimization of the polyurethane precursor composition and content, and the use of alternative surfactants within the cathode inks may permit distinct control of the blowing reaction. These alterations may potentially allow for the microstructural design of the cathode structure, specifically designed for increased TPB population, pore distribution/gradient, oxygen mass flow, and nano-catalyst incorporation.

\section{Acknowledgments}

As part of the National Energy Technology Laboratory's Regional University Alliance (NETL-RUA), a collaborative initiative of the NETL, this technical effort was performed under the RES contract DE-FE0004000.This project was funded by the Department of Energy, National Energy Technology Laboratory, an agency of the United States Government, through a support contract with URS Energy \& Construction, Inc. Neither the United States Government nor any agency thereof, nor any of their employees, nor URS Energy \& Construction, Inc., nor any of their employees, makes any warranty, expressed or implied, or assumes any legal liability or responsibility for the accuracy, completeness, or usefulness of any information, apparatus, product, or process disclosed, or represents that its use would not infringe privately owned rights. Reference herein to any specific commercial product, process, or service by trade name, trademark, manufacturer, or otherwise, does not necessarily constitute or imply its endorsement, recommendation, or favoring by the United States Government or any agency thereof. The views and opinions of authors expressed herein do not necessarily state or reflect those of the United States Government or any agency thereof.

Mr. James Poston and WVU Shared Research Facilities are thanked for their assistance with the SEM and EDS characterization. The authors would also like to thank ANH Refractories Technical Center (West Mifflin, PA) for their assistance with isostatic pressing and Novamet (Wyckcoff, $\mathrm{NJ}$ ) for providing $\mathrm{NiO}$ source powder for evaluation in this work.

\section{References}

[1] Lee S, Miller N, Gerdes K. Long-term stability of SOFC composite cathode activated by electrocatalyst infiltration. J Electrochem Soc 2012;159(7): F301-8

[2] Hojberg J, Sogaard M. Impregnation of LSM based cathodes for solid oxide fuel cells. Electrochem Solid State Lett 2011;14(7):B77-9.

[3] Chang CL, Hsu CC, Huang TJ. Cathode performance and oxygen-ion transport mechanism of copper oxide for solid-oxide fuel cells. J Solid State Electrochem 2003; 7:125-8.

[4] Jiang SP. Nanoscale and nano-structured electrodes of solid oxide fuel cells by infiltration: advances and challenges. Int J Hydrogen Energy 2012;37:449-70.

[5] Jiang SP, Wang W. Fabrication and Performance of GDC-Impregnated (La,Sr) $\mathrm{MnO}_{3}$ Cathodes for Intermediate Temperature Solid Oxide Fuel Cells. J Electrochem Soc 2005;152:A1398-408.

[6] Yamahara K, Jacobson CP, Visco SJ, De Jonghe LC. Catalyst-infiltrated supporting cathode for thin-film SOFCs. Solid State Ionics 2005;176(5-6): 451-6.

[7] Jiang SP. A review of wet impregnation-An alternative method for the fabrication of high performance and nano-structured electrodes of solid oxide fuel cells. J Mater Sci Eng A 2006;418(1-2):199-210.

[8] Huang TJ, Shen XD, Chou CL. Characterization of $\mathrm{Cu}, \mathrm{Ag}$ and Pt added LSCF and gadolinia-doped ceria as solid oxide fuel cell electrodes by temperatureprogrammed techniques. J Power Sources 2009;187:348-55.

[9] Li X, Xu N, Zhao X, Huang K. Performance of a commercial cathode-supported solid oxide fuel cells prepared by single-step infiltration of an ion-conducting electrocatalyst. J Power Sources 2012;199:132-7.

[10] Sholklapper TZ, Kurokawa H, Jacobson CP, Visco SJ, De Jonghe LC. Nanostructured solid oxide fuel cell electrodes. Nano Lett 2007;7(7):2136-41.

[11] Sholklapper TZ, Jacobson CP, Visco SJ, De Jonghe LC. Synthesis of dispersed and contiguous nanoparticles in solid oxide fuel cell electrodes. Fuel Cells 2008;8(5):303-12.

[12] Gansor P, Xu C, Sabolsky K, Zondlo JW, Sabolsky EM. Phosphine impurity tolerance of $\mathrm{Sr}_{2} \mathrm{MgMoO}_{6-\delta}$ composite SOFC anodes. J Power Sources 2012;198:7-13.

[13] Wucherer L, Nino JC. Synthesis and characterization of $\mathrm{BaTiO}_{3}$-based foams with a controlled microstructure. Int Appl Ceram Technol 2009;6(6):651-60.

[14] Rainer A, Basoli F, Licoccia S, Traversa E. Foaming of filled polyurethanes for fabrication of porous anode supports for intermediate temperature-solid oxide fuel cells. J Am Ceram Soc 2006;89(6):1795-800.

[15] Impoco G. Software for the image analysis of cheese microstructure from SEM imagery; 2006.

[16] Vohs JM, Gorte RJ. High-performance SOFC cathodes prepared by infiltration. Adv Mater 2009;21(9):943-56.

[17] Samsonz A, Søgaard M, Knibbe R, Bonanos N. High performance cathodes for solid oxide fuel cells prepared by infiltration of $\mathrm{La}_{0.6} \mathrm{Sr}_{0.4} \mathrm{CoO}_{3-\delta}$ into $\mathrm{Gd}$ doped ceria. J Electrochem Soc 2011;158(6):B650-9.

[18] Huang TJ, Chou CL. Oxygen dissociation and interfacial transfer rate of performance of SOFCs with metal-added $(\mathrm{LaSr})(\mathrm{CoFe}) \mathrm{O}_{3}-(\mathrm{Ce}, \mathrm{Gd}) \mathrm{O}_{2-\delta}$ cathodes. Fuel Cells 2010;10(4):718-25.

[19] Haanappel VAC, Rutenbeck D, Mai A, Uhlenbruck S, Sebold D, Wesemeyer H et al. The influence of noble-metal-containing cathodes on the electrochemical performance of anode-supported SOFCs. J Power Sources 2004;130: 119-28. 